\title{
STUDIES OF HYPERSENSITIVITY WITH MOLD IN ALLERGIC DISEASES OF RESPIRATORY TRACT
}

TAKAHARU SHIMIZU, M.D.

\author{
Section of Oto-Rhino-Laryngology, Sagamihara National Hospital, Research Center of \\ Rheumatology \& Allergology, Kanagarca (Director: Shioda, M.D.)
}

The significance of the mold as an allergen in the allergic diseases of the respiratory tract was studied. The air-borne mold was surveyed for the past five years. The results of the skin test performed on 4510 cases with the respiratory allergic disease were also analyzed. The allergic condition of respiratory tract was generally, divided into two types, upper respiratory type (nasal allergy) and lower respratory type (bronchial asthma).

The IgE concentrations and IgE antibody levels in the sera of 20 cases of each two types were titlated with RIST and RAST. Those levels were compared between each allergen and between each disease type. The results were as follows;

1) Using the slide glass method, ten kinds of the mold spores were identified by the air-borne mold spores survey. The kinds of mold detected were changed every year. However, Alternaria and Epiccccum were observed abundantly every year. The amount of the spores varied seasonally and showed two peaks in early summer and fall. The spores diminished in winter remarkably.

2) The kinds of mold identified with culture plate method also changed every year. The seasonal peak of the amounts of the mold was not always similar to those with slide glass methed.

3) The mold, with which the immediate reaction of the skin test was highly positive, were Candida, Aspergillus, Trichophyton, Penicillium, Cladosporium and Alternaria. And the skin test with Candida and Trichophyton showed positive delayed reaction frequently.

4) Not only IgE concentrations, but also IgE antibody levels of the sera, were higher in the lower respiratory type than in the upper respiratory type.

5) It is suggested that the sensitive organs with mold are selected with the size of the spores. And almost all kinds of the mold, except Alternaria, are considered to be more significant allergen for the allergic diseases of the lower respiratory tract (bronchial asthma) than of the upper one (nasal allergy).

A $81-0448-70869$

\section{気道アレルギーにおける真菌過敏性の検討}

\section{国立相模原病院リュウマチ・アレルギー研究部耳舅科}

清水章治

\section{はじめに}

近年，免疫学やアレルギー学の研究に深い関心が集ま り，気道アレルギー疾患患者の濑增と相まって，日常診 療のらちにもアレルギー性疾患の診断ならびに治療は欠
かせないむのとして次第に普遍化し，浸透してきてい る。

気道アレルギ一疾患に扔いて室内膺や花粉類とならん で真菌類が重要なアレルダン上して実証されてから50余 
年在释過したが1)，今日に至っても真菌アレルギ一の帮 態はほかの2 種の抗原に比較すると，まだ十分解明され ていない点が萝い

真菌によるアレルギ一性疾患としてI型の即時型反心 のみならな゙, Aspergillus fumigatus による开型(アル サス型反゙他）のアレルギー性気管支肺了スペルギルス症 加報告され2，他方，過敏性肺臟炎も真菌によって菱起さ れた型反店の1つであるこヒが知られるに至っだ、IV 型の細胞免疫反応による遅延型反応が気道アレルギーの 発症に関与しているか否加はだ議論も多いが，Candida albicans $\gg$ Aspergillus fumigatus $か ゙$ 皮留反応, 吸 入绫発反底やマクロファージ遊走テストなどの結果から I型反応に関与しているとも指摘され"，真菌によるア レルギー反応は複雑, 多䁌にわたり, 一層理解しにくい との印象を与えている。

そこでわが国における真菌アレルギーの奏態在解明す るために，空中真菌相の検索と多数の気道アレルギー患 者の皮膚テストにより，各種の真菌アレルゲンの感作頻 度を調查し，さらに冼患を上気道型さ下気道型のアレル ギーに大别して，それぞれの臨床所見を分析した。そし て特に重要な真菌アレルゲンにつマて RASTにより IgE抗体の測定在行って雨群間の感作の相違点を比較检 討した。その結果二・三の知見が得られたので報告寸 3.

\section{研究対象ならびに方法}

\section{1. 空中真菌の調查}

空中に浮遊し飛散している真菌胞子を対象上し，1972 年加1976年までの5 年閐観測在行った，検慗の方法は 既塟5 $の$ standard pollen sampling device t用いてス ライドダラォ $1 \mathrm{~cm}^{2}$ 上に落下した真菌胞子の種類上数を 㩆鏡し，同定した。な﨎測は国立相模原病院 5 階屋上。 (地上 $19.5 \mathrm{~m}$ ) に設置された捕集器により，前記と同じ 期間続けた。をして観測された胞子数を各月ごしに平均 Lた.

一方, Mehrlich の修正培地 (malt extract $5 \mathrm{~g}, \mathrm{KH}_{2}$ $\mathrm{PO}_{4} 1 \mathrm{~g}$, peptone $1 \mathrm{~g}$, dextrose $15 \mathrm{~g}$, sodium chloride $75 \mathrm{~g}$, agar $15 \mathrm{~g}$, 蒸溜水老加えて $l$ とする）在内径8 8 cm のペトリ且に流して作製した培拲平板プレートを， 雨天を除いた隔日の午前 9 時に捕集台と同一の場所に設 置し，12分閒空中に露出させた後， $7 \sim 14$ 日間多らん器

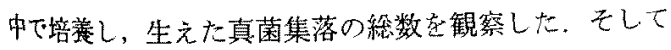
月别の箱落総数をその月の観測甘数で割って1日平均の コロニー数しした。

\section{2. 皮内反忘検查}

対象は1972年か51976年の5 年間に国立相㩰原病院了 レルギーセンターを受診した15才から85才までの成人の 気道了レルギ一舅者 $4,5 \mathrm{i} 0$ 例 (男 2,162 例, 女 2,348 例, 平均年龄37，17士13.76才）である。これら症例に主要な 真菌アレルゲンエキスにより皮内反応検查を行い，その 成績を勧計した。

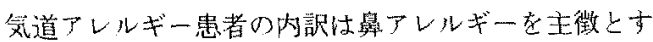
䓃者，743例(男305例，女438例，平均年齢33.16士10.44 才), 氛管支喘息圭主徴上寸る者, 3,767例（男1,846例， 女 1,921 例，平均年齢38.03土13.86才)である.

装 1 に，使用した15種の真菌アレルゲンの真菌学的分 類，種類，製造施設ならびに各胞子の大きさを示した。

表 1 皮内反応検査に用いた真菌アレルゲン

\begin{tabular}{|c|c|c|c|}
\hline 真菌分類 & 種 & $\begin{array}{l}\text { 㿰造 } \\
\text { 施設 }\end{array}$ & $\begin{array}{c}\text { 胞子の大きさ } \\
(\mu)\end{array}$ \\
\hline 藻 菌類 & Mucor & $\mathrm{H}$ & $5 \sim 10$ \\
\hline \multirow{2}{*}{ 子䉴菌類 } & Aspergillus & $\mathrm{T}$ & $3 \sim 4$ \\
\hline & Penicillium & $\mathrm{T}$ & $2 \sim 3$ \\
\hline \multirow{12}{*}{ 不全菌頪 } & Alternaria & $\mathrm{T}$ & $35-90 \times 914$ \\
\hline & Epicoccum & $\mathrm{H}$ & $20 \sim 25$ \\
\hline & Macrosporium & $\mathrm{H}$ & $14-18 \times 20-24$ \\
\hline & Cephalothecium & $\mathrm{H}$ & $8 \sim 16$ \\
\hline & Cladosporium & $\mathrm{T}$ & $4 \sim 18$ \\
\hline & Sepedonium & $\mathrm{H}$ & $8 \sim 11$ \\
\hline & Botrytis & $\mathrm{H}$ & $2-12 \times 3-10$ \\
\hline & Trichophyton & $S$ & $3 \sim 6$ \\
\hline & Fusarium & $\mathrm{H}$ & $2-4 \times 3-6$ \\
\hline & Pulluraria & $\mathrm{H}$ & $2 \sim 6$ \\
\hline & Candida & $\mathrm{T}$ & $5 \sim 5$ \\
\hline & Cephalosporium & $\mathrm{H}$ & $2 \sim d$ \\
\hline
\end{tabular}

詿：H…..Hollister-stier 社製

T......鳥居萝品制

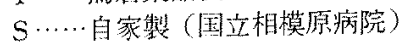

皮内反応検查にはすべて10，000倍の粗抗原エキスを用 いた，即時型皮内反底の陽性判定基準は石筩の分類 ${ }^{6}$ に

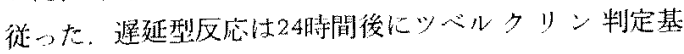
淮つに基ついて硬結，発赤により判定した。

一方，真菌アレルゲン以外の遅延型反応上対比する目 的で倍液の多価細菌ワタチンであるBroncasma Berna

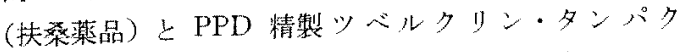
(Hollister-stier 社) 走用いて皮内反店検查を行った。 
3. $\operatorname{IgE}$ 抗体の澌定

鼻アレルギーを主徴とする上気道型アレルギー20例 （男 12 例，女 8 例，平均年龄 $33.35 \pm 12.76$ 才）と気管支 喘息在主徽上する下気道型アレルギー20例（男11例，女 9 例, 平均年秢 $34.00 \pm 13.48$ 才) 索対象上し, 即時型皮 盧反応の陽性率のとくに高い6種の真菌アレルゲン，す な⿰力口一七 Candida, Aspergillus, Trichophyton, Penicil. lium, Cladosporium, Alternaria について RIST によ り血清 $\operatorname{Ig} \mathrm{E}$ 浱度を，また paper disc 妾用いた RAST に上り，そ机无れの抗原に対する血清中の $\operatorname{IgE}$ 抗体聂 を測定した。

RAST に必要な anti-lgE I ${ }^{125}$ は Phadebas RAST kitに添付の材料を用いた， paper disc を担体とした RAST は Ceska ${ }^{8)}$ の方法に淮して行った，皮内反心に 用いた轨述の6種の真菌粗抗原エキ又の100倍液学 pII

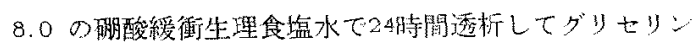
起除いた後、CNBr で活性化して作製した直徍 $5 \mathrm{~mm}$ の 円形 paper disc (東洋濾紙 No.6) に化学的に結合さ せた，抗原上の結合，洗洲拈よび急者血清との混和・保

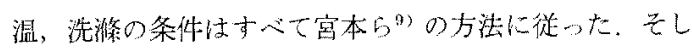
$\checkmark$ paper disc 乙結合した放射能は Aloka Autowell gammer counter

な扩 RAST score は kit 添付の対照血清 A, B, C, D に対与る count 比と比較しての〜 4 まで5段階に分 類した（表 2 ).

表 2 RAST score 0 判定基社

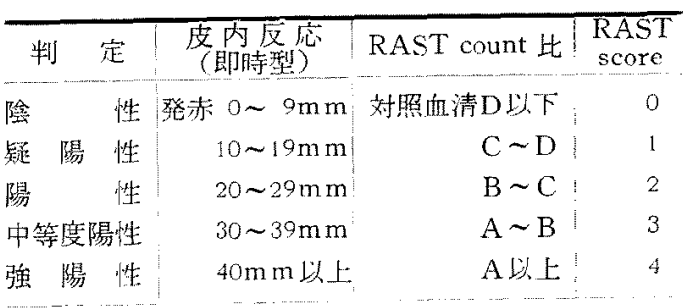

\section{4. ゲル内免疫拉散法:}

前記症例の血清を Ouchterlony 法で，6種の重要真

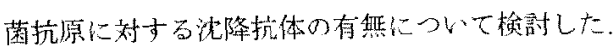

真菌抽出エキ又结非特異的にヒトのCRP を沈降させ る物質が含まれて和り，通常の寒天ダルを用いると CRP の高い患者血清で非特異的沈降線を生じることがあるの T゙10), McI Ivaine 液 (0.1M citric acid $18 \mathrm{ml}, 0.2 \mathrm{M}$ disodium hydrogenphoshate $82 \mathrm{ml}$, sodium azide $0.2 \mathrm{~g}$ ) Ł $3 \%$ Agarose (Behringwerke) 老等量加えて作製し
た寒天ゲルを佣いて，ゲル内沋降反応老行った，寒天中 央の穴 (内径 $8 \mathrm{~mm}$ ) に患者血清を入れ，周辺の穴 (内 径 $5 \mathrm{~mm}$ ) に Candidn, Aspergillus, Trichochyton, Penicillium, Cladosporium, Alternaria の6 種の抗原 を $2 \mathrm{mg} / \mathrm{ml}$ の濃度に加立，3日後に沈降線の有無索判 定した。

\section{結果}

1. 空中真菌の調查成績

a，スライドグラス法による成績

スライドダラス法により同定しえた屋外での空中飛散 真菌胞子は10種で, Aspergillus や Penicillium など胞 子に特徽が少なくしかも光影レベルでは識別困難な微 小真菌は不明として集計した。

表 3 に前記 5 年問の真菌の種類と胞子数年平均值て 示方 量的には Alternaria, Epicoccum, Stemphylium (あるいは Pleospora)，Fusarium がことに多く認めら れ，しかも各胞子の飛散量の年次的変動が著明であ。 た.

表 3 年平均真菌胞子数（スライドダラス法）

\begin{tabular}{l|r}
\hline 飛散真菌の種類 & $\mathrm{M} \pm \mathrm{SD}\left(\right.$ 個 $/ \mathrm{cm}^{2} /$ 年 $)$ \\
\hline Alternaria & $500.8 \pm 183.8$ \\
Epicoccum & $164.4 \pm 33.0$ \\
Stemphylium or Pleospora & $153.8 \pm 114.2$ \\
Fusarium & $1.44 .2 \pm 78.2$ \\
Sepedonium & $90.2 \pm 30.4$ \\
Cladosporium & $88.4 \pm 27.0$ \\
Rust & $70.4 \pm 35.7$ \\
Helminthosporium & $51.8 \pm 33.0$ \\
Curvularia & $38.4 \pm 25.1$ \\
Papullaria & $8.2 \pm 15.7$ \\
不 明 & $306.2 \pm 68.5$ \\
\hline & $1700.6 \pm 365.7$ \\
\hline
\end{tabular}

さらに月别にわけて季節的変動についてみるを，国 にみられる上らに，空中飛散真菌総数で注 6 月上9月に 2 峰性の飛散ピークが証められ，冬期に法著しく減少し ている、10種の真菌胞子数を月別にみると(図2), Alternaria (6月と8月), Epicoccum (6月と10月), Cladosporium (6月上9月) に，季節的に明らかな2 峰性のピークが認めら机た。そしてRust(8月上11月), Helminthosporium（7月と9月）で，わ功に增加す る2峰がみられた。.Sepedonium(8月), Stemphylium 
(Pleospora 含む一9月) \&Fusarium（9月）でリ峰 性のピークがみられ，それに Papullaria ( 7 月) 上 Curuvularia（8月）でわずかに增加の傾间加認められ t.

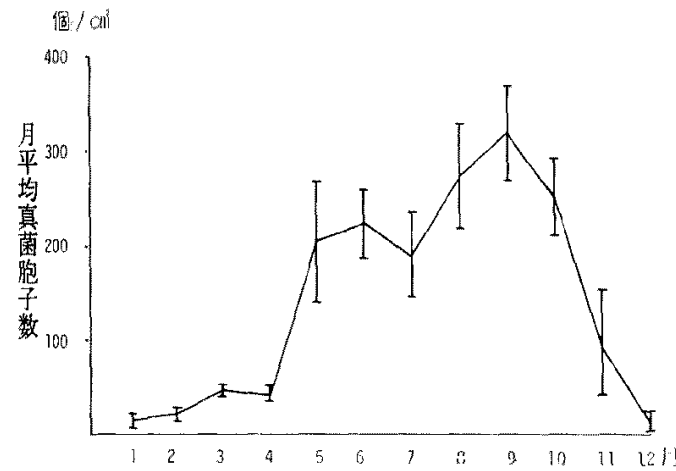

図1月別にみた空中飛散真菌総数（スライド グラス法)

\section{b、培法に上る成續}

5 年間の月別の1日平均集落株数を図3に示した。し かし今回の研究では培養法に上る種類の同定交では行え な加った。

率節的にみると 5 月と10月に2 峰性のピータがみら
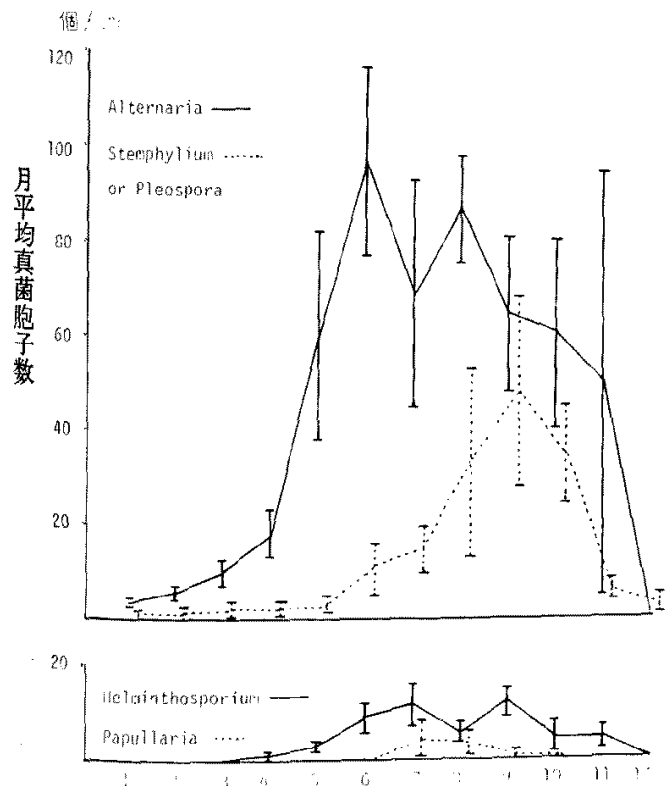

扎，スライドグラス法に上る月则胞子総数の成績と比較 するよ，幾分飛散ピークにずれが翟められ，童的には12 月や1月に至ってもな扮著しい減少がみられず，7月と ほぼ等しい真菌集落数が諗如らた。

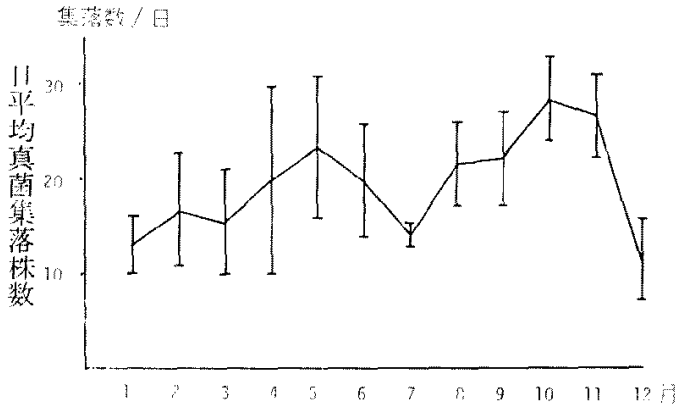

图3月別にみた空中我散真菌集落総数(培養法)

2. 皮内反応検査成績

a 即時型反応の成績

率アレルギーあるいは気管支喘息の気道アレルギー患 者 4,510例に行った主要真菌アレルゲンに上る皮内反応 険查成績を表 4 に示した。

期時型反怠でとくに陽性深の高い真菌をその順にあげ ると, Candida, Aspergillus, Trichophyton, Penicilium,
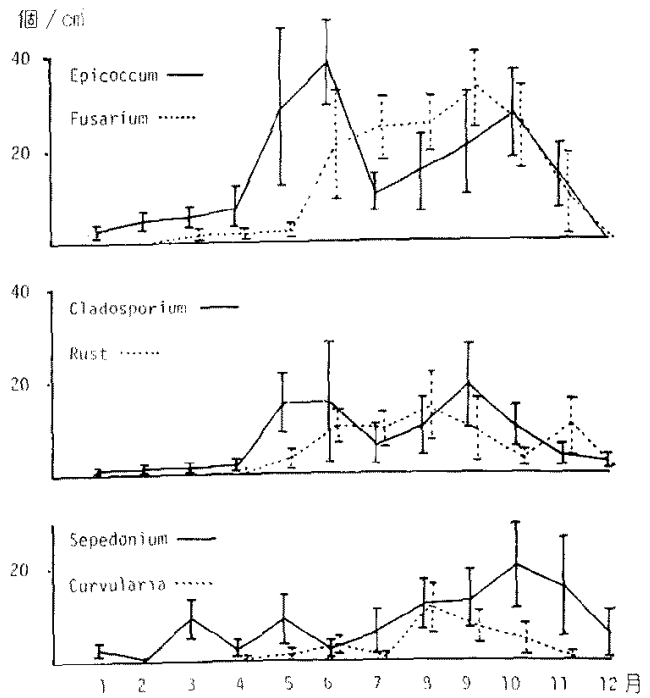

图 2 空中我撒真菌の季節的変動（スライドグラス法） 
表 4 即封型皮内反応検㚗成績

\begin{tabular}{l|r:|c}
\hline 真菌アレルゲン & 対象患者数: 陽 & 性 䒚 \\
\hline Candida & 4,510 & $54.9 \%$ \\
Aspergillus & 4,510 & 24.7 \\
Trichophyton & 2,964 & 16.3 \\
Penicillium & 4,510 & 15.0 \\
Cladosporium & 4,510 & 13.1 \\
Alternaria & 4,510 & 12.2 \\
Cephalosporium & 4,510 & 4.2 \\
Sepedonium & 2,496 & 3.9 \\
Macrosporium & 1,766 & 3.3 \\
Epicoccum & 1,766 & 3.2 \\
Cephalothecium & 3,780 & 3.0 \\
Mucor & 2,964 & 2.9 \\
Fusarium & 1,819 & 2.3 \\
Botrytis & 2,964 & 2.0 \\
Pullularia & 1,766 & 1.8 \\
\hline
\end{tabular}

Cladosporium, Alternaria の6 種で表1に示したように 多くは不全菌類や子囉菌類に属する.

これらの一部は病原性真菌としてヒトに作用するが， このほ加非瘏性の空中真菌，生体に鹰生的に常在方る 雑菌にも高い陽性率が認められた。病原性，人体磨生性 真菌の代表である Candida は $54.9 \%$ と過半数の患者に 陽性の結果が得られた。

つぎに鼻アレルギーを主徴とする上気道型アレルギー 患者のなか力ら200例(男?8例，女122例，平均年齢31.69 土11.35才）と気管支喘息を主徴しする下気道型アレル ギ一患者から200例（男83例，女117例，平均年督 39.29 \pm 12.73 才）妾無作為に抽出し，その皮内反応の陽性率 を病型別に比較したところ，いずれの真菌エキスに対し ても下気道型で陽性率が高かった（表 5).

さらに上括よび下気道型の陽性率を $\mathrm{x}^{2}$ 検定により比 較した結果, Trichophyton, Penicillium, Botrytis の3 種で有意差 $(\mathrm{P}<0.05)$ が認められた。これらはいずれ も2〜10\%の微小真菌であった。

重要真菌 6 種に上る皮内反応陽性率の季節的消長につ いてまとめてみると（図 4), Aspergillus は6月上8月 に影著な2峰性のピークがみられ，Alternaria（6月上 8月）で沬スライドグラス法で観測された胞子の飛散ピ 一タ上全く一致した2峰のピークが認められた. Cladosporium む2月と9月に2峰性のビータがみられたが胞 子飛散のピータとは一致しなかった。このほかPenicil-
表 5 病型別即時型皮内反応陽性率

\begin{tabular}{|c|c|c|}
\hline 類 & $\underbrace{}_{(200 \text { 例 })}$ 道 & $\begin{array}{l}F_{\text {気 道 }} \\
(200 \text { 例 })\end{array}$ \\
\hline Candida & $46.5 \%$ & $54.5 \%$ \\
\hline Aspergillus & 22.5 & 24.0 \\
\hline Trichophyton* & 14.0 & 21.5 \\
\hline Alternaria & 9.5 & 10.5 \\
\hline Cladosporium & 6.0 & 10.0 \\
\hline Penicillium* & 3.5 & 9.5 \\
\hline Mucor & 2.0 & 3.0 \\
\hline Botrytis* & 0.5 & 3.5 \\
\hline Fusarium & 1.5 & 2.0 \\
\hline Cephalosporium & 1.5 & 1.5 \\
\hline Cephalothecium & 1.0 & 2.0 \\
\hline
\end{tabular}

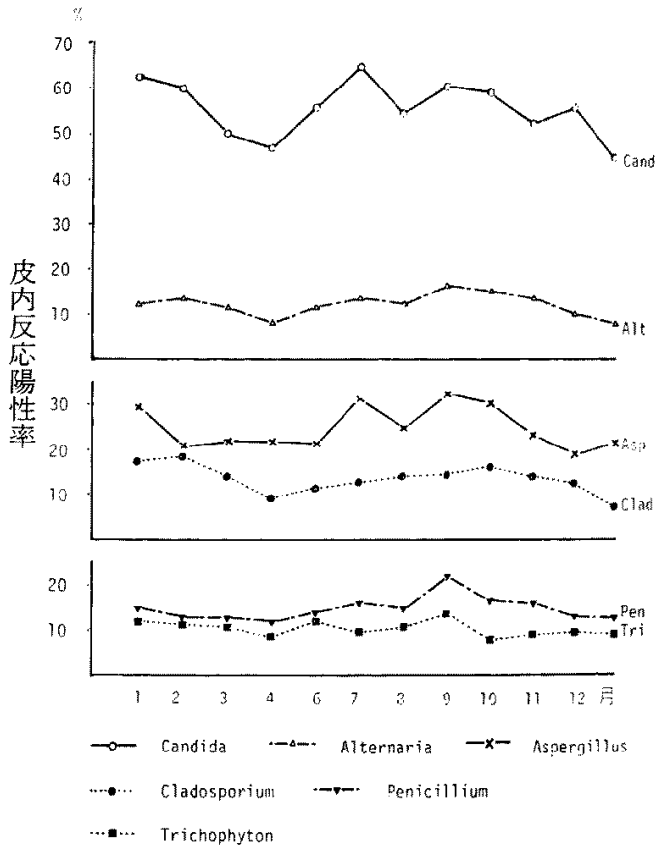

图 4 重要真菌エキスによる皮内反态陽性率の 季節的変動（気道アレルギー400例）

lium P Trichophyton はともに8月に陽性率が最高と なり，Candida性3月と12月を除くと多峰性を示し，1 年を通じて高率に陽性を示した。

同様に重要真菌アレルダンによる陽性率の変動上空中 真菌調查結果とを年次的に比較寸ると(図 5)，スライド ダラス法，培婘法ともに総真菌数の減少はみられないに 
もかかからず，皮内反応の陽性率は6種とも年々減少す る㑯向がみられた。
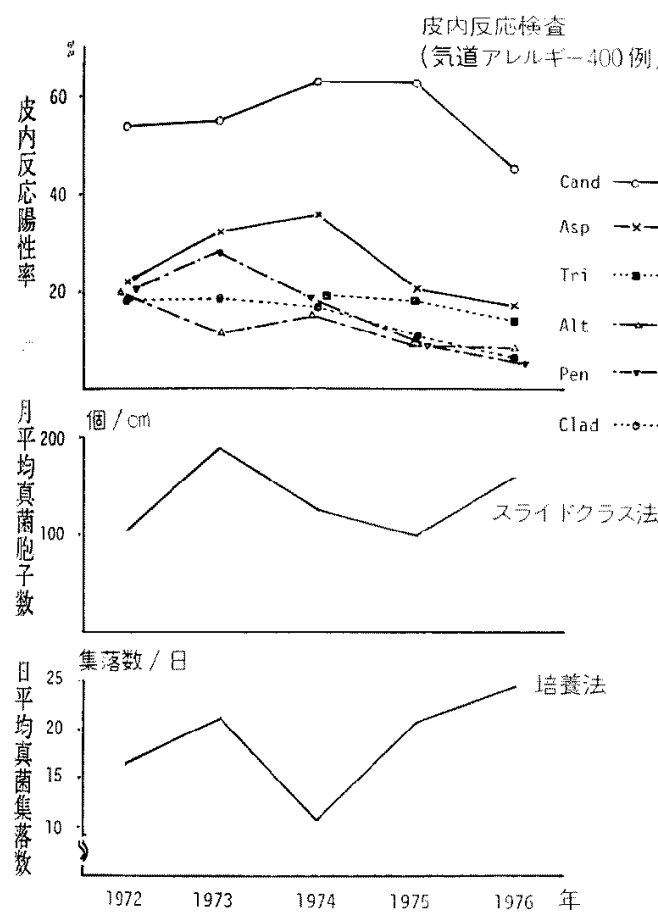

図 5 皮内反応陽性率ならびに空中真菌の年次 的変動

\section{b. 革延型反応}

無作為化抽出した上気道型アレルギー患者 100 例（男

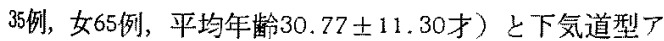
レルギ一患者 100 例（男45例，女55例，平均年龄 36.74 \pm 14.58 才）の遅延型皮内反応陽性率で沬（表 6)，人体 奇生性，深在性真菌である Candida 々 Trichophyton が PPD や Bacteria 製剂である Broncasma Berna と からんで高い陽性率を示したが，病型別にはいずれのア レルゲンにっレても有意差は認められなかった。

3. RASTに上る $\operatorname{IgE}$ 抗体の測定

上および下気道型アレルギーで重要真菌 6 種の5ち,

米数以上の真菌アレルゲンエキスに同時に陽性を示した 各20例ずつ計40例の血清 $\operatorname{IgE}$ 抗体を RAST により測 定した。

これらの患者の RAST による血清中 $\operatorname{IgE}$ 值の平均 生上気道型1047.83土1237.51U/ml, 下気道型1324.43土 1599.77U/ml と両群々も高值を示したが，下気道型で
表 6 病型别遅延型皮内反応陽性摔

\begin{tabular}{|c|c|c|}
\hline 類 & $\begin{array}{c}\text { 上気 道 型 } \\
(100 \text { 列) }\end{array}$ & 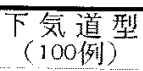 \\
\hline $\mathrm{PPD}$ & $62 \%$ & $67 \%$ \\
\hline Candida & 66 & 63 \\
\hline Trichophyton & 55 & 46 \\
\hline Broncasma Berna $(\times 10)$ & 43 & 48 \\
\hline Cladosporium & 8 & 11 \\
\hline Aspergillus & 8 & 10 \\
\hline Penicillium & 8 & 8 \\
\hline Alternaria & 4 & 5 \\
\hline Botrytis & 0 & 2 \\
\hline
\end{tabular}

\section{とくに高い傾向にあった。}

表 2 に示した基淮に従って即時型皮内反応の強さと RAST score との関倸を6 種の荲要真菌アレルダンにつ いて検討してみる上，上気道型で相関係数 $0.25(N=120$, $t=2.80, P<0.01)$, 下気道型で相関保数 $0.41(\mathrm{~N}=$ $120, \mathrm{t}=4.89, \mathrm{P}<0.01)$ と両群とも $1 \%$ の危険率で 有意に相関し，真菌アレルダンエキスに上る即時型皮内 反応の強さは患者血清中の $\lg E$ 抗体量とほぼ平行してい ることがわかった。

つぎに真菌アレルグンによる即㭙型皮内反応陽性で RAST 陽性（RAST score 2 以上）を示した症例を病 型ならびに抗原別に分類すると(表 7$)$ ，明らかに下気道 型アレルギー患者は上気道型に比べて RAST の陽性率 が高く，Yates の修正を扰こなった適合度検定によると Candida, Cladosporium, Penicillium @ 3 種に $5 \%$ の

表 7 抗原別 RAST 陽性率（sccre による）

\begin{tabular}{|c|c|c|c|c|c|}
\hline \multirow[t]{3}{*}{ 病 型 } & 抗 原 㣍 & $\begin{array}{l}\text { 皮内テ } \\
\text { ス卜陽 } \\
\text { 性 }\end{array}$ & $\begin{array}{l}\text { RAST } \\
\text { 晹 性 }\end{array}$ & 一致率 & $\begin{array}{l}\text { RAST } \\
\text { 陽性率 }\end{array}$ \\
\hline & Aspergillus & 18 & 3 & $25 \%$ & $16.7 \%$ \\
\hline & Candida & 20 & 0 & 0 & 0 \\
\hline \multirow{4}{*}{$\begin{array}{c}\text { 上気道型 } \\
\text { (20例) }\end{array}$} & Alternaria & 16 & 4 & 40 & 25.0 \\
\hline & Cladesporium & 14 & 0 & 30 & 0 \\
\hline & Penicillium & 14 & 0 & 30 & 0 \\
\hline & Trichophyton & 13 & 2 & 35 & 15.4 \\
\hline \multirow{2}{*}{ 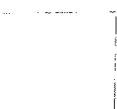 } & Aspergillus & 20 & 9 & $45 \%$ & $45.0 \%$ \\
\hline & Candida & 18 & 11 & 55 & 61.1 \\
\hline 下気道型 & Alternaria & 19 & 8 & 45 & 42.1 \\
\hline \multirow[t]{3}{*}{ (20例) } & Cladosporium & 19 & 4 & 25 & 21.1 \\
\hline & Penicillium & 19 & 9 & 50 & 47.4 \\
\hline & Trichophyton & 19 & 9 & 50 & 47.4 \\
\hline
\end{tabular}


表 8 抗原别 RAST count 比

\begin{tabular}{|c|c|c|c|c|}
\hline 程類 & 上気道型 $M \pm S D(\%)$ & 下気道型 $\mathrm{M} \pm \mathrm{SD}(\%)$ & $t$ & 定 \\
\hline Aspergillus & $3.89 \pm 3.03(\mathrm{~N}=18)$ & $11.04 \pm 9.52(\mathrm{~N}=20)$ & $\mathrm{t}=2.99$ & $9(P<0.01)$ \\
\hline Candida & $2.92 \pm 1.40(N=20)$ & $10.14 \pm 8.45(N=18)$ & $\mathrm{t}=3.68$ & $8(P<0.01)$ \\
\hline Alternaria & $5.96 \pm 7.08(N=16)$ & $8.21 \pm 6.88(N=19)$ & $\mathrm{t}=0.93$ & $3 \quad \mathrm{NS}$ \\
\hline Cladosporium & $3.01 \pm 0.96(N=14)$ & $5.06 \pm 2.87(\mathrm{~N}=19)$ & $t=2.57$ & $7(P<0.02)$ \\
\hline Penicillium & $3.20 \pm 1.85(N=14)$ & $8.73 \pm 6.27 \quad(\mathrm{~N}=19)$ & $\mathrm{t}=3.25$ & $5(P<0.01)$ \\
\hline Trichophyton & $3.15 \pm 1.93(\mathrm{~N}=13)$ & $6.54 \pm 3.86(N=19)$ & $t=2.91$ & $(P<0.01)$ \\
\hline
\end{tabular}

危険率で有意差が認められた。

さらに RAST count の平均百分辈で6種の真菌アレ ルダン別に検定を行った成續を表 8 に示す count 比に よる群間比較を行ったところ，Alternaria 除く，他の 5 種恃す心て下気道型で有意に高い $\mathrm{IgE}$ 抗体量が喼的ら れ，上気道よりもむしろ下気道で真菌アレルギーが発症 しやすいことがわかった。

\section{4. ゲル内免疫拉散法による成績}

$\operatorname{IgE}$ 值ならびに $\mathrm{IgE}$ 抗体測定の対象とした 40例の真 菌過敏患者血清について検討したところ，2例（上気道 型!例，下気道型1例）が Candida に対してのみ，1 本の沈降線が会合して認められ，他の5種は寸心゙て沈降 抗体がみられなかった。

なお Candida に対古沈降反应陽性の2 例はいずれ も RAST score がのであり，N型のアレルギーが関与 していることが示㥖された。

\section{考案}

真菌アレルギーはオランダのVan Leewen (1924) が Aspergillus, カナダの Cadhan (1924) が Wheat rust による気管支喘息班例報告したのが初めとされて、 る. Feinberg（1935）慎菌が花粉についで重要なアレ ルゲンと考え，空中生物学との閶連を指摘し，Durham （1938）恃米国内63ケ所で調查した空中真菌の地理的,

李節的相違乞对比して耀告している，一方，英国では Hyde $5(1946)$ 吕应範囲に空中の真菌を調查してい る(1)，以後，今日まで世界各地域に执いて空中真菌相の 調查が行われている。

一般に㙬中真菌相は温度, 湿度, 気流, 風速, 天候な どの地理的, 気象条件の相違によって大きく影缶される ので12)13，真菌によるアレルギ一性疾患の蹺床的意義を 理解寸るためには，それぞれの地城に扔ける空中真菌胞 子の種類上多案を倠測し，把握しておくことが必要であ る。すなら，真菌アレルギーの診断に用いるアレルゲ ンエキスは当颜地域にみられる空中真菌相の種類に従。
て慎重に選択されなければならない，治療效果の判定

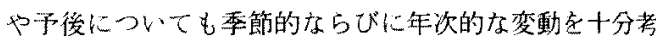
㤫した上で論じられる心゙きである

1. 空中真菌の調査成績について

空中の真菌調查寸る方法として，スライドグラス法 および培差法が一般的であるが，このほが衝笑扰よび 回転アーム捕集器，情速吸引捕集器，吸引衝突培養法老 嘴えたAndersen 捕集器などが用いられている方)15y，後 者の特殊な捕集器によるものは前の 2 方法に比心゙，より 正確な定量的捕集が可能であるが，かなり操作が繁䧴

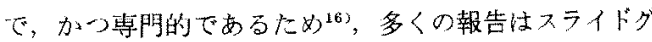
ラス法または培養法によって調查が行われている

空中飛散花粉調查に一般的なスライドグラス法b真菌 では胞子が小さく，整いので強風や雨の影響を受けや才 $<$, Aspergillus, Penicillium, Candida, Trichophyton など5 以下の微小で，かつ重要な真菌胞子の同定が難 かしいなどの久点がある。一方, Cladosporium は形態 上の特徽が少ないが，ややこれらの真菌より大きく、胞 子が塊としてみられることが多いのだ Alternaria と同 様に同定はそれほど困難ではない。またスライドダラス 法は操作が簢単で24時問の真菌相が空中心飛散する花粉 の多塞と併行して観察できることや捕集用基剂として使 われているワセリンが真菌を増殖させないので，長期に 保存した標本をあとで見直せるなどの利点も多い（17)

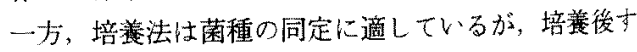
くに観察しないと生えすぎて同定が不可能となったり， 空中に暴露する特間が短いので(通常は10分前後)，調查

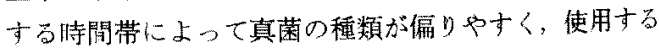
境地によ一ては生えにくい真菌があるなとと欠点があ 古

スライドグラス法と培養法の結果がかならずしも一致 しなかったのは Shapiro ${ }^{13}$ 子認めるところであり，前述 したよらに方法や観測時間が全く異なるためと考えられ 万. 
スライドグラス法や锫養法から得られた成續によると Alternaria, Cladosporium 在主娎等中真箱としている

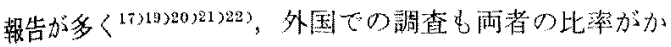
ならずしもー致していないしかし，李節的な变動につ いてはほぼわれわれの成績上一致している，2番目に多 く覞察された Epicoccum については，カリホルニアで Shapiro(日), 本邦では降短 ${ }^{203}$ が重要視している。束た FusariumはDupont ら

量的にはスライドグラス法で観測したCladosporiumが 諸家の報告1319324ほど多〈認められなかっったが、これは 地城的な暹いによるものと考无られた。

5 年間にかたる調查がら空中真菌数が年次的に者しく 変動することが明らがなった。これは先に述心たよう ないつかの気象条件が年每心大き变化す无ためと舁 わ机る。過去の報告ては長期にわたる報告はきわわて少

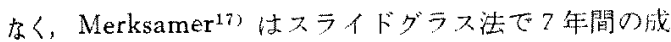
績在報告しているが，年次的庄差については触扎ていな

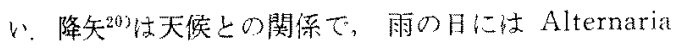
が隇るが，Aspergillus 伎かならすしも少なくならない ので，前者は屋外性，㣪者は屋内性に时来するであるう

と推論している。

また空中の真菌相洨地域的にも，また同じ地域ても桪

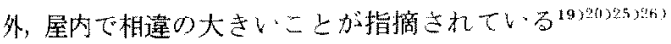

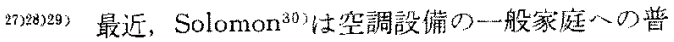
及加，七くに Aspergillus p Penicillum tと座内性真 菌の堌殖を招いたと警告している。

今回の調查で林スイドグすス法による同定上併行し て培養法での菌種の同定走で位できなかったが，とくに 微小な空中真菌相の検索には大ライドダタス法上培差法 と併用してみてゆくことが必要であるとの結論を得 t.

\section{2. 真菌過敏性の検查成績について a 対象}

一般にアレルボ一性疾患の䍜患率には性差はないが， 加路により変動がみられるので，真菌アレルギ一も当然 この点老考慮しなければならない＼cjkstart本研㚾では15才以上 の主として成人の気渞アレルギ一患者在対象とし，上招

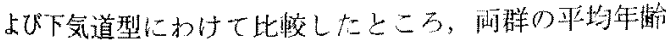
はともに30才代で，年龄的な佰よりはみられなかった。

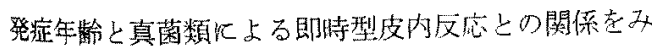
た高橋31によれ代，若年発症者に上?に高い陽性率がみ

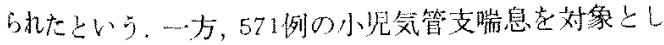
t島貫 $5^{32}$ 仗 Candida $31.8 \%$, Cladosporium $14.5 \%$ ，

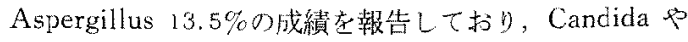
Aspergillusなどの微小真菌ではもしろ成人在対象とし

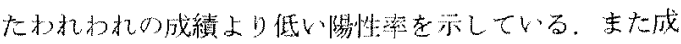
人七異なり，小昌ては Alternaria や Cladosporium 0

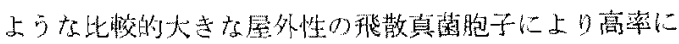
感作されていることは，後过するように离腔の広さと真

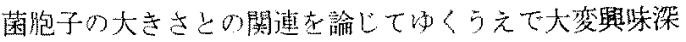

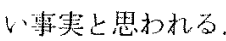

b 、助時型反店

即時型反応では Candida や Trichophyton のように 人体腐生性病原性真菌で最方高く, ついて Aspergillus, Penicillum たど主として屋内性の真菌に，さらに Alternaria や Cladosporiumな $と$ 主として晸外性の真菌の 順に高、陽性制在示した。

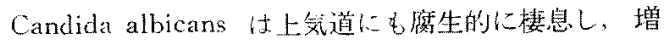

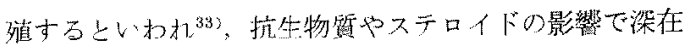
性にむ表在性にも七トの常在性真菌として存在するの で、気道アレルギーに占める役制は複雑である方: Candidaによる皮虔テストの診断的な意義は少ないとする 説もあるが34：一部の陽性者に上って気道に捛ける吸入

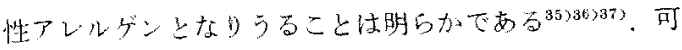

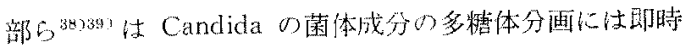

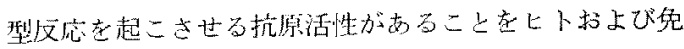
投したモルモ％トの吸入テストで証明している，岸本 ${ }^{40}$ は Candida 抗原添加に上万ラットのマスト細胞脱顆粒

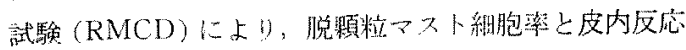

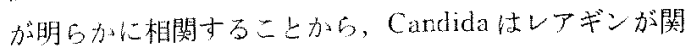

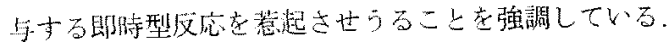

また paper dise に上る RAST 使った秋山ら 1120 恰枽ては皮内反忘，誘発テス卜ともよく相関が力られた とし, Candicla 抗原の $\operatorname{IgE}$ によっていき起こされる反 心に蛋白於関与していると推論している。現行のCNBr

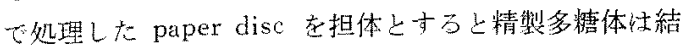
各しにくいしの都告42がある。しかし，paper discによ

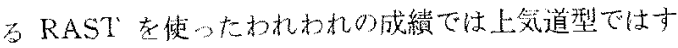
心て陰性，下気道型で61.1\%00陽性淘吕得られ，疾患に よって陽性率心明らかな相違がみられる心で, paper dise 担体としても真菌に特翼的な抗体量をほぼ满足 さきる程度に测定しうると考えられた。

走たこれらの成績から，友内反応心際には Candida

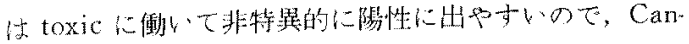
didaによる真菌悱舆アレルギーの钐数は慏重に行われ るぶきだあると侤えられた。 
トリコフィチン皮内反応は白狼菌の診断に皮膚科領域 で広く用いられ，ことに樑在性白獾で陽性率が高いとい

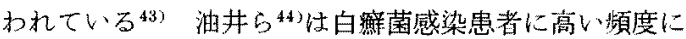
アトピー型の Trichophyton 调敏喘息がみられたと報告 している，われわれの症例でも RASTにより，上気道 型で15.4\%，下気道型で47.4\%の陽性率が得られた。

Aspergillus については東ら ${ }^{45}$ が Aspergillus fumigatus の抗原分析を行い，精製多糖体が即時型反応起 こすと報告している，同じくRAST の成績では上気道 型で16.7\%，下気道型で $45.0 \%$ が陽性を示した。

Alternaria では皮内反応陽性率が空中真菌の多塞上よ く一致した成績が得られたが，これは Alternaria が他 の真菌類に比べてきわだって強い皮膚反応を示すという Lewis ${ }^{46)}$ の報告をある意味で裹づけて扰り，Alternaria 注抗原性の強さや飛散量と臨床症状上が一致才る点に㧍 いて花粉のそれと類似するところが多いと考えられる。 Alternaria では上気道型で $25.0 \%$ ，下気道型で $42.1 \%$ が RAST 陽性であった。

その他, Cladosporium や Penicillium では上気道型 の20例がす心゙て RAST 除性で，抗体量の面からみれば 鼻アレルギーのアレルゲンとなる頻度はきわめて少ない と考元られた。

c 遅発型反応

皮内反応による遮延型反応では Candida $上$ Tricho phytonに上捛よび下気道型でともに高い陽性率がみら れた。

これらの菌が病原性真菌として真菌症を惹起すること は広く知られているが，アレルゲンとして作用する際に は即時型のみならずアルサス型, 途延型の反応をしばし ば呈する，PPD や細菌の皮内反応の陽性率上ほぼ一致 することから，感染と何らかの深い関連があることが示 唆される，先に述べた可部は Candida の抗原を分析し て，蛋白分画あるいは末分画粗抗原が遅延型反応老起こ すことをみている。一方, Pepys $5^{3347 \text { は }}$ は Candida albicans や Aspergillus fumigatus が型のアルサス 反応にも関与していると報告している。

ダル内免疫㹡散法で検璟した結果，2例が Candida にのみ沈降抗体が証明され，Candidaによる迤発型のア レルギーが存在する可能性が示された。

d. 病型别の成績

皮内反応，血清中の $\operatorname{IgE}$ 值抢よび $\lg$ E 抗体量のいず 机の成績で比較しても, 明らかに上気道型よりも下気道 型アレルギー患者がより強く真菌アレルゲンに感作され
ている成績が得られたが，これは中山ら格が内科，小児 科，耳鼻科，皮膚科など 6 施設での真菌エキス皮内反底 検盉を集計して得た成績上よく一致している。

RASTに上る抗体量の面加らると上気道型てはAl. ternaria, Aspergillus, Trichophyton $の$ 順比, 下気道型 では Candida, Trichophyton, Penicillium, Aspergillus, Alternaria, Cladosporium の順に真菌アレルダンとして 重要であることがわかった。

自然界にある10万種以上に柱よぶ真菌のなかで，アレ ルギー性疾患上関倸あるものは20３0種に過ぎないとさ れている Bulmer ${ }^{50)}$ は多くの空中真菌の報告から Alternaria, Aspergillus, Botrytis, Cephalcsporium, Chaetomium, Fusarium, Helminthosporium, Cladosporium, Monilia, Mucor, Penicillium, Pulluaria, Rhizopus, Rhodotorula, Saccharomyce の15種拉よび皮 膚系状菌皮疹の診断として Microsporium, Epidermophyton, Trichophyton, Candida $の 4$ 種を加之, 重要真菌 アレルゲンと指摘している.さらに最近では Giannini51) が空中真菌調查でほとんど㭘出されない胞子類でも吸入 性アレルグン上して無視できないものがあると報告して いる.

空中真菌調查で同定した10種の真菌のうち皮内反応娭 查に用いたのは 5 種に過ぎないが，胞子飛散量の多算上 陽性率とはか子就ずしも平行せす，真菌にも拉とらく花 粉と同様に，抗原性の強弱が存在するように思わ扎る。 空中飛散暴ならびに皮内反応の陽性率を月別にみてゅく と多くの真菌で6月と8〜9月に2 峰性のピークがみら れることから，ことにこの時期を mold season と考え， 真菌アレルダンを十分考慮に入れてアレルゲンの診断に あたる心゙きであると考えられた。

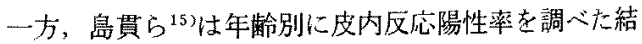
果，6〜7才で最も高く，年路が長ずるに従い陽性率が 低下したといら。

これまでみてきたように病型や年齢によって気道に掞 ける真菌過敏性に大きな相違がある事実から，アレルゲ 二物質の大きさによって発症臟器や好発年㛔が選択され ているのではないかと思われる。平均して20 $\mu$ 前後の花 粉粒ては眼鼻症状を主徵とする花粉症が発定しやすく ${ }^{522}$ ，

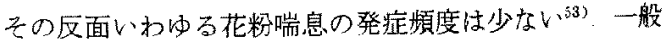
に10\%以上の粒子は100\%上気道で除加れ，5 そ80\%が，さらに小粒子流そのまま肺に吸い込まれ，1

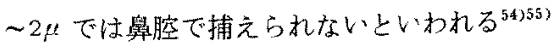

真菌胞子の大きさはかならずしも一定ではないが，先 
に示したように Alternaria 除くほとんどが 10 以以下 の胞子でことに重要真菌アレルダンである Candida, Aspergillus, Trichophyton, Penicillium など, 多くは 平均して $3 \mu$ ないしは $4 \mu$ 前後なので㢣腔で捕捉される 機会がきわめて少ない

胞子の大きさや空中飛散量, 皮内反応, RAST の成 績などを考えあわせると，上気道型アレルギーで最も重 要な真菌アレルダンは Alternaria であり、このことは RAST count 比による群間比較の結果加らも証明され た.

本来，大気中物質のフィルターとしての働きをしてい る劓悾で捕捉されない微小真菌胞子はさらに哚部の気管 支粘莫まで容易に到達し，比較的高い頻度で下気道アレ ルギーを発症させているものと考えられる。Alternaria による鼻アレルギーが学童期に発症率が高く，成人での 発症率がきわめて低、とい5日常臨床的な事実も，西る い注に鼻腔内の広さに基因しているのかも知九ない。

\section{まとめ}

気道アレルギーにおおる真菌アレルゲンの臨床的な意 義を明らかにする目的で，1972年から1976年むでの5 年 間, 空中の真菌の実態を調查した。一方，4,510例の気 道アレルギー患者について皮膚反応検查，血清中 $\operatorname{IgE}$ 值 · $\lg E$ 抗体量などについて検討し，以下の結論在得た。

1。スライドグラス法で同定しうる空中真菌胞子は種類 が限られるが，Alternaria，Epiccccum などが最も多く 観察された。季節的にみると初夏と秋に增加の傾向がみ られ，冬期はほとんど飛散が諗められなかった。一方， 年次的には飛散量の変動が著しく，これは主として気象 条件の相違に起因していると考えられた，

2. 培羡法によっても年次的に変動が大きかったが，李 節的に注冬期飞も比較的多く認められ，飛散のピークは スライドグラス法とかならずしも一致しなかった。

調查の方法により，結果に差があり，このため架中真 菌の調查はスライドダラス法上培羕法上を併用して観察 寸る必要があると考えられた。

3. 皮内反応娭查では，a 即時型に Candida, Asper gillus, Trichophyton, Penicillium, Cladcsporium, Al. ternaridの 6 種の真菌アレルダンで高い隄性率を走し，

気道アレルギーを上気道型と下気道型の 2 群に分けて比 敕すると，下気道型のアレルギーでより陽性率が高い結 果加得られた。

年次的な皮内反応陽性率は空中真菌心量的減少がみら 机なにも加わらず，各真菌アレルゲンとも年タ減少 の傾向がみられた，b，崌延梨では Candida，Trichophyton の2 種の人体需生, 梁在性真菌による偒性率が 高く、この2 種の真菌アレルダンは $\mathrm{I}$ 型のみならず, $\mathrm{NV}$ 型の反忘をも示すことから感染型のアレルギーの意義も 否定できない

4. 真菌過敏患者の血清中 IgE 值は雨気道型とも高值を 示したが，下気道型でより高く，6種の重要真菌アレル ダンに対する $\operatorname{IgE}$ 抗体量も Alternaria 除き, 上気道 型に比心，下氮道型で高い結果が得ら机た。

5. 真菌の胞子はその多くが上気道で捕捉されないぐら い微小なものであることから，真菌アレルゲンは臨床的 な意昧に执いて下気道型アレルギーにより重要性がある 上考えら机た。

\section{文献}

1) Prince H.E., et al.: An up-to-date look at mold allergy. Ann. Allergy, 37; 18-25, 1976.

2) McCarthy D.S., et al.: Allergic bronchopulmonary aspergillosis. Clin. Allergy, 1; 415-426, 1971.

3) Pepys J.: Pulmonary aspergillosis, farmer's lung, and related diseases. Immunological $\mathrm{di}$. sease, 1; 693-713, Little, Brown and Co., Boston, 1971.

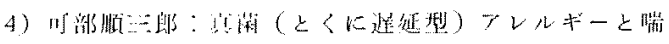
息. フレルギー、21；511-522，1972.

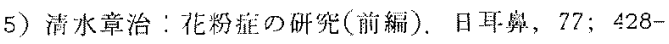
440, 1974.

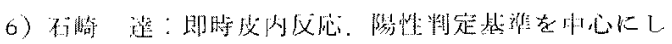
て.フレルギー, 12; 14-30, 1963

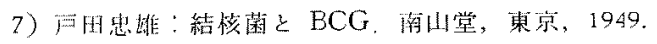

8) Ceska M., et al.: Radioimmunosurbent assay of allergen. J. Allergy Clin. Immunol., 49; 1-9, 1972 .

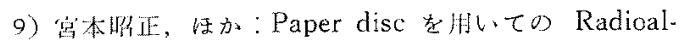

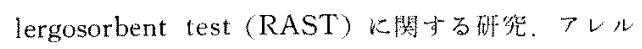
ギー. 22; 584-593, 1973.

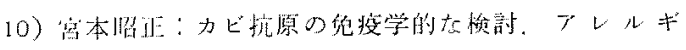
- 21:526-529, 1972.

11) Maunsell K.: Respiratory allergy to fungus spores. Prcgress in allergy, 4; 457-517, Little, Brown Co., Boston. 1955.

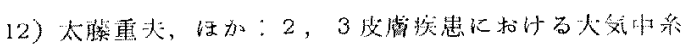

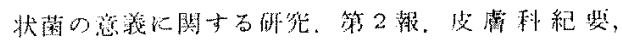
56; 205-208, 1961. 


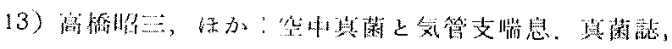
$15 ; 3-10,1974$.

14) Solomon W.R.: Aeroallergens. A manual of clinical allergy, second edition, 326-436. W.B. Saunders Co., London, 1967.

15) Southworth D.: Introduction to the biology of airborne fungal spores. Ann. Allergy, 32; 1-22, 1974.

16) Pandy S.M., et al.: Diumal perodicity in airborne fungal spores, Ann. Allergy, 39; 302-310, 1967.

17) Merksamer D., et al.: An evaluation of atomospheric mold spores as allergen in the New York metropolitan area; a seven-year study. J. Allergy, $29 ; 60-71,1958$.

18) Shapiro R.S., et al.: Airborne fungi in Los Angeles, Calfornia. J. Allergy, 36; 472-425, 1965.

19) Durham O.C.: Incidence of air-borne fungus spores. J. Allergy, 10; 40-49, 1938.

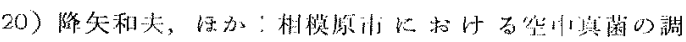
查.アレルギー, 2I：45?-465, 1972.

21) Collins-Williams C., et al.: Atomospheric mold counts in Tronto, Canada, 1971. Ann. Allergy, $31 ; 69-71,1971$.

22) Finegold 1.: A two-year pollen and spore survey of Southeast Florida. Ann. Allergy, 35; 37-41, 1975.

23) Dupont E.M., et al.. A Survey of the airborne fungi in the Albuquerque, New Mexico, metropolitan area. J. Allergy, 39; 238-244, 1967.

24) Collins-Williams C., at al.; Atmospheric mold counts in Tronto, Canada. J. Allergy, 26; 468$470,1955$.

25) Richards $M$., et al.: Atomosperic mold spores in and out doors. J. Alleryy, 25; 429-439, 1954.

26) Long D.L., et al.; Air spora of two contrasting ecological sites in Kansas. J. Allergy, 49; 255 $266,1972$.

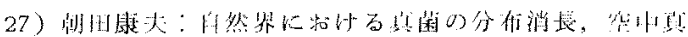

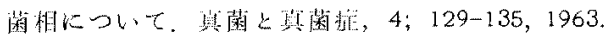

28) Lumpkins E.D., et al.: Airborne fungi survey. 1. Culture-plate survey of the home environment. Ann. Allergy, 31; 361-369, 1973.

29) Lumpkins E.D., et al.: Airborne fungi survey. 2.
Culture plate survey of the home environment Ann. Allergy, 36; 40-44, 1976.

30) Solomon W.R.; A volumetric study of winter fungus prevalence in the air of midwestern homes. J. Allergy Clin. Inmunol, 57; 45-55, 1976.

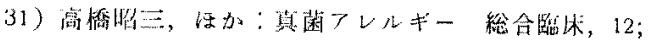
$2209-2215,1972$.

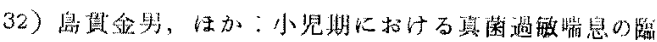

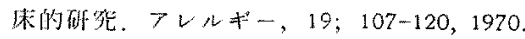

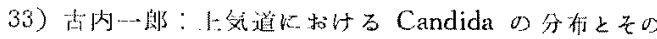

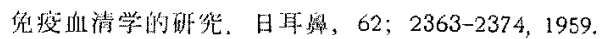

34) Salvin S.B.: Allergic reactions to pathogenic fungi. Textbook of immunopathology. 1; 323336, Grune, Stratton, New York, 1968.

35) Itkin I.H., et al.: Bronchial hypersensitivity to extract of Candida albicans. J. Allergy, 37; 187$194,1966$.

36) Kurimoto $Y$ : Relationship among skin tests bronchial challenge and serology in house dust and candida albicans allergic athma. Ann. Al lergy, $35 ; 131-141,1975$.

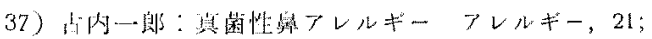
$469-476,1972$.

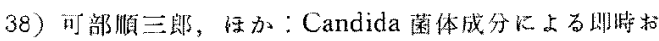

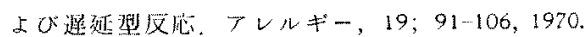

39) Kabe J., et al.: Antigenicity of fractions from extracts of candida albicans. J. Allergy, 47; 5975,1971 .

40) 紫本照思: Candida hypersensitivity 2 reagin $\infty$ 相関火ついての in vitro テス卜 鿓菌誌, 14; 13$19,1973$.

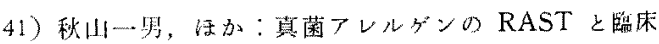

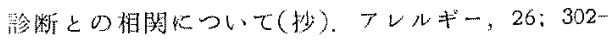
303,1977 .

42) 保柖正, 棌名: Radioallergosorbent test(RAST)

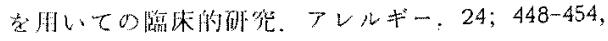
1975 .

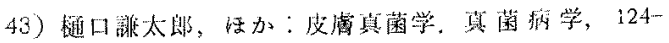
147，金原结版，東京，1964。

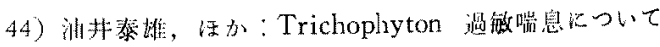
(抄)。フレルギー，25; 337-338, 1976.

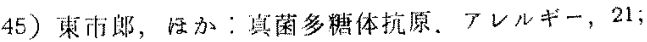


466-469, 1972.

46) Lewis W.H., et al. Allergy epidermolcgy in the St. Louis, Missouri, area, 1. Fungi. Ann, Al. lergy, 34; 374-383, 1975

47) Pepys J., et al.: Candida albicans percipitins in respiratory disease in man. J. Allergy, 41; 305-$318,1968$.

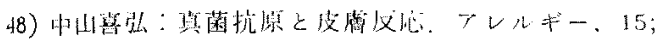
$567-576,1966$.

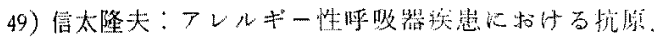
医撩, 30；1044-1052, 1976.

50) Bulmer G.: Fungi and fungus allergy. Clinical immunology and allergy, second edition, 35157\%, Grune, Stratton, New York, 1969.

51) Gianini E.H., et al.: The allergenic significance of certain fungi: Rerely roported as allergens. Ann. Allergy, 35; 372-376, 1975.

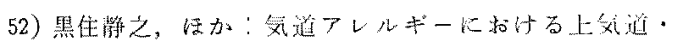

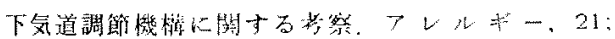
$441-456,1972$.

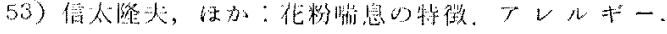
$19 ; 739.751,1970$.

54) Browen J.H., et al.: Influence of particle size upon the retention of particule matter in human lung. Am. J. Public Health, 40; 450-458, 1950.

55) Lichtenstein L.M., et al: Pathogenesis of allergic rhinitis. Immunological disease, second edition, 825-839, Little, Brown, London, 1971.

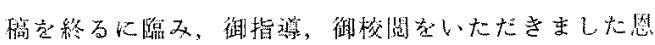

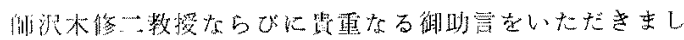

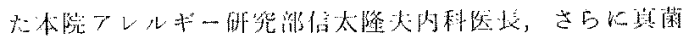

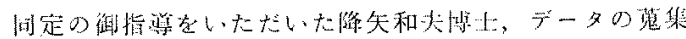

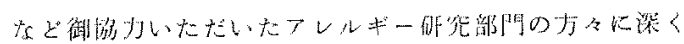

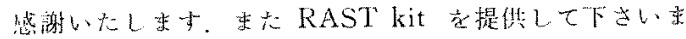

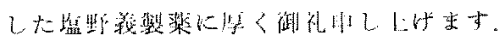

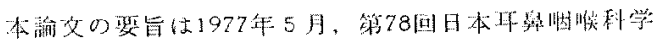

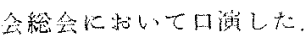

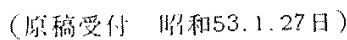

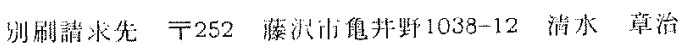

